\title{
Joanna Wegner-Kowalska*
}

Zdrowie jest stanem zupełnej pomyślności fizycznej, umysłowej i społecznej, a nie jedynie brakiem choroby lub ułomności. [...] Rządy ponoszą za zdrowie swych ludów odpowiedzialność, której mogą sprostać tylko przez przewidzenie odpowiednich środków zdrowotnych i społecznych ${ }^{1}$.

\section{ZDROWIE CZLOWIEKA JAKO PRZEDMIOT OCHRONY PRAWA ADMINISTRACYJNEGO}

Zdrowie należy do kategorii tych dóbr osobistych, które mają charakter naturalny, przyrodzony, obiektywny i niezależny od aktualnej treści prawa pozytywnego obowiązującego w danym systemie. Dobro osobiste naturalne istnieje nawet wtedy, jeżeli brak odnoszącej się doń jakiejkolwiek regulacji, w tym zwłaszcza ochronnej w porządku prawnym. Ponadto wszelkie regulacje odnoszące się do dóbr naturalnych mogą być wyłącznie deklaratoryjne, stwierdzające, opisujące ich istotę; nie mogą dóbr naturalnych ustanawiać, czy przyznawać2. Jednocześnie rozsądny ustawodawca obowiązany jest do ochrony dóbr naturalnych, jako szczególnych atrybutów osoby ludzkiej. Ochrona ta winna szanować jego samoistny charakter tych dóbr.

Konstytucja RP potwierdza prawo każdego do ochrony zdrowia. Poszczególne ustępy artykułu 68 ustawy zasadniczej, zamieszczonego w rozdziale „Wolności i prawa ekonomiczne, socjalne i kulturalne" niosą w tej sferze bogatą treść. Odnoszą się do prawa do ochrony zdrowia jako prawa człowieka, prawa przedmiotowego, czyli ustawodawstwa poświęconego ochronie zdrowia ${ }^{3}$ oraz zawierają normy programowe. Stanowiąc o prawie każdego do ochrony zdrowia przepisy konstytucyjne odzwierciedlają bimorficzność zdrowia jako dobra naturalnego. Dwoistość ta wyraża się w tym, iż zdrowie jest zarówno indywidualnym dobrem

* Dr, Kancelaria Adwokacka adwokat Joanna Wegner-Kowalska, Łódź.

${ }^{1}$ Preambuła do Konstytucji Światowej Organizacji Zdrowia z 22 lipca 1946 r., Dz. U. z 1948 r., nr 61, poz. 477 ze zm.

2 A. Kidyba, Kodeks cywilny. Komentarz, Warszawa 2012, t. I, s. 50.

3 J. Jończyk, Zasady i modele ochrony zdrowia, „Państwo i Prawo” 2010, nr 8, s. 3. 
osobistym jednostki, jak i dobrem publicznym ${ }^{4}$, rozumianym jako stan zdrowotności ludności, populacji i skutkuje niejednorodnymi narzędziami ochrony tego dobra. Po pierwsze, przepis art. 68 ust. 1 Konstytucji zobowiązuje ustawodawcę do kreowania ustaw o takiej treści, które pozwolą jednostce na ochronę indywidualnego, naturalnego dobra osobistego i w tym rozumieniu można go odczytywać jako normę programową. Zaznaczyć jednak należy, że programowy charakter normy nie oznacza dowolności po stronie ustawodawcy; norma programowa może bowiem zostać naruszona ${ }^{5}$. Po drugie, dotyczy zdrowia jako prawa człowieka, publicznego prawa podmiotowego ${ }^{6} \mathrm{i} \mathrm{w}$ tym aspekcie należy omawianej treści konstytucyjnej przyznać walor normatywny, realizujący się w konkretnym roszczeniu 7 . Treścią prawa podmiotowego jest w tym wypadku realna możliwość korzystania z systemu zdrowia, funkcjonalnie ukierunkowanego na zapobieganie chorobom, urazom i niepełnosprawności na poziomie minimalnej ochrony praw człowieka ${ }^{8}$.

Programowy charakteru regulacji konstytucyjnej oznacza, że poza ochroną minimalnego poziomu zdrowia, zwykle nie jest wystarczająca dla ustalenia sytuacji prawnej jednostki w przypadku pojawienia się zewnętrznego zagrożenia naruszenia zdrowia czy uchybienia temu dobru. Ustawodawca zwykły winien przecież zapewnić jednostkom należyte środki ochrony zarówno przed zagrożeniem naruszenia, jak i przed atakiem przeciwko zdrowiu. Czyni to zarówno na gruncie prawa prywatnego, jak i prawa publicznego. O ile rolą norm prawa prywatnego jest stworzenie instrumentów prawnych gwarantujących ochronę w postaci akcji podejmowanej z inicjatywy samego pokrzywdzonego, na podstawie jego własnej, suwerennej decyzji wobec równego sobie podmiotu, tak zadaniem norm prawa publicznego jest uregulowanie ochrony podejmowanej przez orga-

${ }^{4}$ Rozumiane jako desygnat nazwy dobro wspólne, tak R. Hauser, Z. Niewiadomski, A. Wróbel (red.), System prawa administracyjnego, t. VII, Prawo administracyjne materialne, red. R. Hauser, Z. Niewiadomski, A. Wróbel Warszawa 2012, s. 145.

5 J. Trzciński wyróżnia trzy takie przypadki: 1) gdyby ustawodawca niewłaściwie zinterpretował przepis Konstytucji, wyznaczający określony cel czy zadanie władzy publicznej, w szczególności uchwalając ustawę, zastosował takie środki, które nie mogły doprowadzić do realizacji założonego w konstytucji celu, albo gdy zastosował zbyt słabe środki, np. dał za słabe fundusze dla realizacji określonego celu; 2) gdyby ustawodawca uchwalając ustawę naruszył istotę wolności lub prawa, a więc naruszył art. 31 ust. 3 Konstytucji, który odnosi się także do norm programowych; 3 ) gdyby ustawodawca regulując jakieś prawo lub wolność uczynił to poniżej minimum tego prawa, minimum wyznaczonego najczęściej przez istotę prawa; nie może być mniej praw nić wynika to $\mathrm{z}$ istoty prawa; por. J. Trzciński, Konstytucyjne prawo do zdrowia na tle art. 35 Karty praw podstawowych Unii Europejskiej, [w:] L. Garlicki, A. Szmyt, Sześć lat Konstytucji Rzeczypospolitej Polskiej. Doświadczenia i inspiracje, Warszawa 2003, s. 304 i cytowany tam orzeczenie TK z 19 listopada 1996 r., sygn. akt K 7/95, OTK 1996/cz. II/42.

6 J. Jończyk, op. cit., s. 3.

7 Por. szczegółowe omówienie charakteru prawnego art. 68 Konstytucji przedstawione przez J. Trzcińskiego, op. cit., s. 299-305.

8 Por. wyrok SN z 21 grudnia 2004 r., sygn. akt I CK 320/04, LEX nr 369249, J. Trzciński, op. cit., s. 305. 
ny administracji publicznej w sposób władczy w stosunku do jednostek głównie z urzędu, lub na wniosek uprawnionych podmiotów ${ }^{9}$. Ochrona ze strony prawa prywatnego dotyczy wyłącznie dóbr konkretnych jednostek i podejmowana jest wyłącznie $\mathrm{w}$ ich interesie, $\mathrm{z}$ ich inicjatywy ${ }^{10} \mathrm{i}$ w pełni na ich koszt (z wyjątkami płynącymi z instytucji zwolnienia od kosztów sądowych), zaś czynności podejmowane $\mathrm{w}$ oparciu o przepisy prawa publicznego dokonywane są w przede wszystkim w interesie publicznym na rzecz ogółu społeczeństwa z reguły na koszt Skarbu Państwa (ewentualnie właściwej jednostki samorządu terytorialnego), lub - z rzadka z częściowym obciążeniem jednostki kosztami postępowania w ściśle określonych przypadkach po zakończeniu postępowania.

Władcza ochrona zdrowia ludzkiego stanowiona przez normy prawa publicznego ${ }^{11}$ realizuje się w gałęzi prawa karnego oraz prawa administracyjnego. Sposób, kierunki kształtowania polityki karnej należą w przeważającej mierze do swobodnej decyzji ustawodawcy, leżącej poza sferą ochrony minimalnego poziomu ochrony zdrowia, z wyjątkiem tych przypadków, w których władza publiczna wkracza przymusowo w sferę osobistą jednostki ${ }^{12}$. W wykonaniu tych założeń ustawodawca wprowadził szereg przepisów Kodeksu karnego ${ }^{13}$, w tym - jego Części ogólnej ${ }^{14}$ i Części

9 Szerzej na temat rozróżnienia prawa prywatnego i prawa publicznego por. np. M. Pyziak-Szafnicka (red.), Kodeks cywilny. Część ogólna. Komentarz, Warszawa 2009, s. 12-14, J. Nowacki, Prawo publiczne - prawo prywatne, Katowice 1992, s. 8-50.

${ }^{10}$ Głównie według norm wywodzonych z art. 23-24 i art. 444-448 kodeksu cywilnego, por. szerzej na ten temat np. A. Szpunar, Uwagi o funkcjach odpowiedzialności odszkodowawczej, „Państwo i Prawo" 2003, nr 1, s. 17-26.

${ }^{11} \mathrm{Na}$ temat zróżnicowania systemu prawnego i uwarunkowania historycznego podziału na gałęzie por. T. Chauvin, T. Stawecki, P. Winczorek, Wstęp do prawoznawstwa, Warszawa 2011, s. $141-147$.

12 Mam tu na myśli np. obligatoryjne czynności medyczne, którym poddać się zmuszony jest podejrzany w świetle art. 74 § 2 pkt 2 k.p.k., czy powinność zapewnienia ochrony prywatności pokrzywdzonego lub świadka, którym grozi niebezpieczeństwo osobiste w związku z prowadzeniem postępowania karnego (art. $156 \S 5$ a, art. $184 \S 1$ k.p.k.).

13 Ustawa z 6 czerwca 1997 r. - Kodeks karny, Dz. U. nr 88, poz. 553 ze zm.

14 Jak w art. $42 \S 3$ k.k. obligujący sąd do orzeczenia zakazu prowadzenia wszelkich pojazdów mechanicznych na zawsze, jeżeli sprawca w czasie popełnienia katastrofy w ruchu lądowym, wodnym lub powietrznym, którego następstwem jest śmierć innej osoby lub ciężki uszczerbek na jej zdrowiu, albo w czasie popełnienia przestępstwa spowodowania śmiertelnego lub skutkującego ciężkim uszczerbkiem na zdrowiu wypadku w ruchu lądowym, wodnym lub powietrznym był w stanie nietrzeźwości lub pod wpływem środka odurzającego lub zbiegł z miejsca zdarzenia, art. 47 k.k. uprawniający sąd do orzeczenia nawiązki na rzecz Funduszu Pomocy Pokrzywdzonym oraz Pomocy Postpenitencjarnej w przypadku skazania sprawcy za umyślne przestępstwo przeciwko życiu lub zdrowiu albo za inne przestępstwo umyślne, którego skutkiem jest śmierć człowieka, ciężki uszczerbek na zdrowiu, naruszenie czynności narządu ciała lub rozstrój zdrowia, a także w razie skazania sprawcy za przestępstwo spowodowania wypadku lub katastrofy w ruchu lądowym, wodnym lub powietrznym, jeżeli sprawca był w stanie nietrzeźwości lub pod wpływem środka odurzającego lub zbiegł z miejsca zdarzenia sąd może orzec nawiązkę na rzecz Funduszu Pomocy Pokrzywdzonym oraz Pomocy Postpenitencjarnej, art. 58 § 2 a k.k. wyłączający możliwość orzeczenia kary ograniczenia 
wolności, jeżeli stan zdrowia oskarżonego wyłącza możliwość wykonania pracy społecznie użytecznej, art. $64 \S 2$ k.k. statuujący instytucję recydywy szczególnej wielokrotnej dla sprawcy ponownie dopuszczającego się przestępstwa przeciwko m.in. życiu lub zdrowiu, art. 95a § 1 k.k. zakazujący prowadzenie terapii farmakologicznej wobec sprawcy przestępstwa przeciwko wolności seksualnej, jeżeli taka terapia mogłaby zagrażać życiu lub zdrowiu skazanego, art. $105 \S 2$ k.k., wyłączający możliwość zastosowania instytucji przedawnienia wobec umyślnego przestępstwa: zabójstwa, ciężkiego uszkodzenia ciała, ciężkiego uszczerbku na zdrowiu lub pozbawienia wolności łączonego ze szczególnym udręczeniem, popełnionego przez funkcjonariusza publicznego w związku z pełnieniem obowiązków służbowych, art. $115 \S 21$ definiujący pojęcie występku chuligańskiego jako m.in. umyślnego zamachu na zdrowie lub nietykalność cielesną.

15 Jak zwłaszcza regulacje zawarte w rozdziale XIX - Przestęstwa przeciwko zdrowiu $i$ życiu, rozdziale XX - Przestępstwa przeciwko bezpieczeństwu powszechnemu, rozdziale XXI - Przestępstwa przeciwko bezpieczeństwu w komunikacji i rozdziale XXII - Przestępstwa przeciwko środowisku, a także inne przepisy, np. art. 118 § 1-3 k.k. penalizujące zbrodnię ludobójstwa, art. 118a $\S 1-3$ k.k. zawierające sankcję za spowodowanie zamachu terrorystycznego, art. $123 \S 1-2$ odnoszące się do zbrodni zabójstwa lub ciężkiego uszczerbku na zdrowiu, stosowania tortur w stosunku doludności cywilnej na obszarach okupowanych lub w stosunku do jeńców wojennych, art. 140 $\S 2$ k.k. normujący przestępstwo zamachu przeciwko siłom zbrojnym Rzeczypospolitej, art. 220 $\S 1$ regulujący odpowiedzialność karną pracodawcy za narażenie pracownika na niebezpieczeństwo w pracy, art. 223 § 2 dotyczący czynnej napaści na funkcjonariusza publicznego, której skutkiem jest ciężki uszczerbek na zdrowiu, art. 224a k.k. penalizujący fałszywe zawiadomienie instytucji publicznej o masowym zagrożeniu życia zdrowia ludzkiego, art. 254 § 2 k.k. stanowiący o odpowiedzialności za udział w zgromadzeniu dokonującym zamachu na osobę lub mienie, art. 282 k.k. odnoszący się do przestępstwa wymuszenia rozbójniczego, art. 354 § 1 i 2 k.k. obejmujący odpowiedzialnością karną nieostrożne obchodzenie się bronią przez żołnierza skutkujące uszczerbkiem na zdrowiu, art. $355 \S 1$ i 2 k.k. regulujący odpowiedzialność za spowodowanie wypadku w ruchu lądowym, wodnym lub powietrznym przez żołnierza.

16 Jak np. art. 15 § 3 k.p.k. przewidujący szczególną ochronę osób nieporadnych ze względu na stan zdrowia, art. $74 \S 2$ pkt 2 k.p.k., nakazujący szanowanie zdrowia i życia oskarżonego podczas przeprowadzania niezbędnych badań psychologicznych, psychiatrycznych, badań połączonych z dokonaniem zabiegów na jego ciele, zabiegów pobrania krwi, włosów lub wydzielin organizmu, art. 156 § 5a k.p.k., uprawniający prokuratora do odmowy zgody podejrzanemu lub jego obrońcy na udostępnienie akt m.in. wówczas, gdy zachodzi uzasadniona obawa, że narażałoby to na niebezpieczeństwo utraty życia lub zdrowia pokrzywdzonego lub innego uczestnika postępowania, art. 184 $\S 1$ k.p.k. obligujący organy procesowe do zachowania w tajemnicy danych świadka lub osoby dla niego najbliższej, jeżeli zachodzi uzasadniona obawa niebezpieczeństwa dla życia, zdrowia tych podmiotów (tzw. mały świadek incognito), art. 202 § 1 i nast. k.p.k. odnoszący się do sposobu ustalania zdrowia psychicznego oskarżonego, art. 232a § 1 i nast. k.p.k. zobowiązujący organy procesowe do przechowywania przedmiotów i substancji stwarzających niebezpieczeństwo dla życia lub zdrowia, a w szczególności broń, amunicję, materiały wybuchowe lub łatwopalne, materiały radioaktywne, substancje trujące, duszące lub parzące, środki odurzające, substancje psychotropowe lub ich preparaty oraz prekursory kategorii 1, w miejscu i w sposób zapewniający ich należyte zabezpieczenie, art. $259 \S 1$ pkt 1 zawierający negatywną przesłankę stosowania tymczasowego aresztowania w postaci zagrożenia dla życia lub zdrowia oskarżonego oraz pkt 2 tego przepisu służący za podstawę do odstąpienia od tymczasowego aresztowania, jeżeli tego rodzaju zagrożenia dotknęłyby osoby najbliższe oskarżonemu, art. 260 k.p.k. nakazujący wykonywanie środka w postaci tymczasowego aresztowania tylko w odpowiednim zakładzie leczniczym, jeżeli stan zdrowia oskar- 
wykonawczego ${ }^{17}$, przepisów karnych zawartych w ustawach szczególnych, składających się na coraz szerszą dziedzinę prawa karnego pozakodeksowego ${ }^{18}$. Prawo karne w szerokim rozumieniu ${ }^{19}$ obejmuje również normy prawa wykroczeń i postępowania w sprawach o wykroczenia. Instrumenty ochrony życia i zdrowia ustanowiono więc również w poszczególnych przepisach ${ }^{20}$ kodeksu wykroczeńn ${ }^{21}$ i przepisach ${ }^{22}$ kodeksu postępowania karnego ${ }^{23}$. Ujmując rzecz bardzo ogólnie, ochrona prawnokarna dokonywana jest w przypadku prawa materialnego - z punktu widzenia społecznej szkodliwości konkretnego czynu, czy jak w ustawie procesowej - z uwagi na konieczność zapewnienie niezbędnej ochrony poszczególnych podmiotów postępowania. Nie stanowi zasadniczego przedmiotu zainteresowania prawa karnego pozytywna troska o bezpieczeństwo zdrowotne społeczeństwa; nie jest zadaniem prawa karnego ustanawianie norm to bezpieczeństwo zabezpieczających, lecz wyłącznie takich, które penalizują czyny popełnione wbrew ustawie i uznane za społecznie szkodliwe o stopniu większym niż znikomym. Można zatem stwierdzić, że instytucje prawa karnego wykorzystywane są następczo, gdy zdrowie jednostki (a w niektórych przypadkach - zdrowie powszechne) zostanie już naruszone, lub narażone na niebezpieczeństwo.

żonego tego wymaga, art. 563 k.p.k. przewidujący jako okoliczność wpływającą na zastosowanie prawa łaski również stan zdrowia skazanego, art. 592c § 3 k.p.k. zakazujący udzielenia informacji o zastosowanych w postępowaniu środkach zapobiegawczych, a także innych informacji właściwemu organowi państwa członkowskiego Unii Europejskiej, jeżeli miałoby narażałoby to uczestnika postępowania na niebezpieczeństwo utraty życia lub zdrowia, art. 607n § 2 k.p.k. tamujący przekazanie państwu obcemu osoby ściganej, jeżeli wiązałoby się to z zagrożeniem dla jej życia lub zdrowia, art. $607 \mathrm{w}$ pkt 15 stanowiący o bezwzględnym wykonaniu europejskiego nakazu aresztowania, nawet gdy w świetle prawa polskiego czyn nie jest przestępstwem, jeżeli przestępstwo polega na spowodowaniu ciężkiego przestępstwa na zdrowiu.

17 Ustawa z 6 czerwca 1997 r. - Kodeks karny wykonawczy, Dz. U. nr 90, poz. 557 ze zm.

18 Por. np. art. 96 i nast. ustawy z 25 sierpnia 2006 r. o bezpieczeństwie żywności i żywienia, Dz. U. z 2010 r., nr 136, poz. 914 ze zm., art. 36 ustawy z 15 grudnia 2000 r. o Inspekcji Handlowej, Dz. U. z 2009 r., nr 151, poz. 1219 ze zm., art. 14 ustawy z 30 marca 2001 r. o kosmetykach, Dz. U. z 2013 r., poz. 475.

19 Por. więcej na ten temat np. A. Marek, Kodeks karny. Komentarz, Warszawa 2010, tenże, Prawo wykroczeń, Warszawa 2012, s. 3, 2; T. Grzegorczyk (red.), Kodeks wykroczeń. Komentarz, Warszawa 2010, s. 2.

20 Jak np. w przepisach zawartych w rozdziale X Wykroczenia przeciwko bezpieczeństwu osób i mienia, rozdziale XI Wykroczenia przeciwko bezpieczeństwu i porządkowi w komunikacji, rozdziale XII Wykroczenia przeciwko osobie, rozdziale XIII Wykroczenia przeciwko zdrowiu.

${ }^{21}$ Ustawa z 20 maja 1971 r. - Kodeks wykroczén, Dz. U. z 2013r, poz. 482 ze zm.

22 Jak np. w art. $42 \S 2$ k.p.w. regulujący ochronę zdrowia obwinionego w sytuacji podejrzenia co do stanu jego zdrowia psychicznego i innych, odsyłających do treści kodeksu postępowania karnego, np. art. $44 \S 5$ k. p. w., odsyłający m.in. do art. 232a k.p.k., art. $54 \S 5$ k.p.w., odsyłający do art. $74 \S 3$ k.p.k.

${ }^{23}$ Ustawa z 24 sierpnia 2001 r. - Kodeks postepowania karnego, Dz. U. z 2013 r., poz. 395 ze zm. 
Oczywiście należy brać pod uwagę również funkcję prewencyjną prawa karnego, zarówno indywidualną, jak i generalną, jednakże samo zagrożenie odpowiedzialnością karną nie wskazuje w jaki sposób zapewnić właściwą ochronę zdrowia ludzkiego.

O ochronie zdrowia publicznego mówić można szerzej na gruncie drugiej z wymienionych wcześniej gałęzi prawa publicznego - prawa administracyjnego. Zdrowie jako dobro podlega ochronie prawa administracyjnego, ponieważ stanowi wartość o znaczeniu publicznym. Zabezpieczanie dóbr publicznych należy do funkcji prawa administracyjnego ${ }^{24}$. Prawnoadministracyjnej ochronie poddawane jest zarówno zdrowie powszechne, rozumiane jako zdrowie całego społeczeństwa, jak i mniejszej zbiorowości. Jednocześnie w ramach ochrony zdrowia publicznego dobro jednostki może także zostać objęte ochroną, jeżeli stan zdrowia jednostki może oddziaływać na stan zdrowia powszechnego. Przypomnieć wypada, że zdrowie ludzkości zostało uznane przez społeczność międzynarodową za dobro zasługujące na ochronę na wysokim poziomie. Jedne z najstarszych obowiązujących aktów prawa międzynarodowego poświęcone są $\mathrm{w}$ całości właśnie ochronie zdrowia publicznego ${ }^{25}$, inne - uwzględniają w swych postanowieniach dbałość o to dobro ${ }^{26}$. Przedwojenne akty prawa międzynarodowego (wskazane

${ }^{24}$ Por. J. Zimmermann, Prawo administracyjne, Warszawa 2012, s. 34-41.

${ }_{25}$ Por. np. Międzynarodowa Konwencja Sanitarna z 17 stycznia 1992 r., Dz. U. z 1933 r., $\mathrm{nr}$ 17, poz. 133, poświęconej zabezpieczeniu jednostek przed rozprzestrzenianiem się chorób zakaźnych na skutek podróży i transportu międzynarodowego, Międzynarodowa Konwencja Opiumowa z 23 stycznia 1923 r., Dz. U. nr 9, poz. 55, stanowiąca kontynuację prac konferencji międzynarodowej zorganizowanej w Szanghaju w 1909 r., w której postanowiono przedsięwziąć stopniowe sthumienie nadużycia opium, morfiny, kokainy, tudzież przetworów lub pochodnych substancji tych prowadzących lub mogących prowadzić do podobnych nadużyć (preambuła), zob. szerzej United Nations Information Centre Press Release z 22 lutego 1999 r., http://www.unic.un.org.pl/incb/98. traktaty.pdf, Konwencja i Statut o utworzeniu Unii Międzynarodowej Niesienia Pomocy, akt końcowy z 12 lipca 1927 r., Dz. U. z 1933 r., nr 6, poz. 35, ustanawiająca ciało do niesienia pomocy: 1. w klęskach, spowodowanych siłą wyższą, a których wyjątkowy rozmiar przekracza siły i środki dotkniętego narodu, przyjść danej ludności z pierwszą pomocą i w tym celu skupić darowizny, środki oraz wszelkiego rodzaju akcje wspomagające, 2. we wszystkich klęskach publicznych, o ile możności, koordynować wysiłki, czynione przez organizacje niesienia pomocy, tudzież w sposób ogólny pobudzać do badań i do akcyj zapobiegawczych przeciw klęskom i pośredniczyć, ażeby wszystkie narody wykonywały wzajemną międzynarodową pomoc (art. 2), porozumienie w sprawie ułatwień marynarzom handlowym leczenia chorób wenerycznych z 1 października 1924 r., Dz. U. z 1933 r., nr 13, poz. 92, Międzynarodowa konwencja sanitarna dotycząca żeglugi powietrznej z 12 kwietnia 1933 r., Dz. U. z 1936 r., nr 8, poz. 84 ze zm., Konwencja międzynarodowa o zwalczaniu zaraźliwych chorób zwierzęcych z 20 lutego 1935 r., Dz. U. z 1939 r., nr 26, poz. 172 ze zm., Konstytucja Światowej Organizacji Zdrowia z 22 lipca 1946 r., Dz. U. z 1948 r., nr 61, poz. 477 ze zm.

26 Jak np. Konwencja o uproszczeniu formalności celnych z 3 listopada 1923 r., Dz. U. z 1931 r., nr 106, poz. 819, która zagwarantowała uprawnienie do wprowadzania dodatkowych ograniczeń przywozowych z uwagi na zagrożenie życia lub zdrowia (por. art. 13 art. 17 zdanie II, ust. 1 Protokołu), Międzynarodowe porozumienie dotyczące wywozu skór z 11 lipca 1928 r., Dz. U. z 1931 r., nr 35, poz. 728 , ustanawiające wyjątki od swobody handlu skórami m.in. w przypadku zagroże- 
tutaj tylko przykładowo) na trwałe wyznaczyły węzłowe materie prawne ochrony zdrowia publicznego funkcjonujące również obecnie, a które podlegają sukcesywnemu wzbogacaniu o kolejne, w miarę rozwoju ludzkości. Dostrzec można, że ochrona zdrowia publicznego dokonywana za pomocą norm prawa administracyjnego kreowanego w obrębie kilku filarów:

1. Pierwszy obejmuje akty prawne poświęcone zdrowiu publicznemu w ogólności, generalnej ochronie zdrowia poprzez ustanawianie instrumentów służących zapewnieniu odpowiedniego stanu zdrowotności społeczeństw, poprzez wykonywanie czynności badawczych, prac naukowych, analitycznych, eksperymentalnych. Normy należące do tej grupy definiują niebezpieczeństwa dla zdrowia publicznego, instrumenty monitorowania zagrożeń, kreują lub wskazują organy, którym powierzają zadania zabezpieczające bieżącą ochronę zdrowia publicznego, aktywność na polu naukowym. Znajdują się w tej dziedzinie umowy międzynarodowe ${ }^{27}$, akty prawa unijnego ${ }^{28} \mathrm{i}_{\text {krajowego }}{ }^{29}$.

2. Drugi obszar dotyczy leczenia i zwalczania chorób wyróżnionych ze względu na wysoki stopień ich zagrożenia dla organizmu ludzkiego, łatwość, szybkość przenoszenia, sprowadzanie wysokiej śmiertelności; poświęcony jest wskazaniu tych chorób, które według aktualnego stanu wiedzy medycznej uznawane są jako zakaźne, uregulowaniu zasad udzielania informacji o stanie zdrowia publicznego, w tym w szczególności pojawiania się nowych chorób zakaźnych i ich ruchu $^{30}$, sposobu i trybu ustanawiania obszarów ochronnych, procedur wymiany

nia zdrowia publicznego (art. 4 ust. 4), Międzynarodowe porozumienie dotyczące wywozu kości, Dz. U. z 1931 r., nr 95, poz. 726 ustanawiające wyjątki od swobody handlu kośćmi surowymi lub odtłuszczonymi, jak również ich odpadkami, rogami, pazurami i kopytami, jak również ich odpadków do wyrobu kleju m.in. w przypadku zagrożenia zdrowia publicznego (art. 4 ust. 4).

27 Takie jak Konstytucja Światowej Organizacji Zdrowia z 22 lipca 1946 r., Dz. U. z 1948 r., nr 61, poz. 477 ze zm.

${ }^{28}$ Jak przede wszystkim Karta praw podstawowych Unii Europejskiej, Dz. U.UE.C.2007.335.1, art. 168 Traktatu o funkcjonowaniu Unii Europejskiej, Dz. U. z 2004 r., nr 90, poz. 864/2 ze zm., jak też akty niższego rzędu, np. rozporządzenie (WE) nr 851/2004 Parlamentu Europejskiego i Rady z 21 kwietnia 2004 r. ustanawiające Europejskie Centrum ds. Zapobiegania i Kontroli Chorób (Dz. U. UE. L. 2004.142.1 ze zm.), na temat ochrony zdrowia w Unii Europejskiej por. I. Wrześniewska-Wal, Wspólnotowe regulacje prawne w obszarze zdrowia publicznego, „Prawo i Medycyna” 2004, nr 17, s. 98, M. Paszkowska, Ochrona zdrowia w Unii Europejskiej, „Prawo i Medycyna” 2004, nr 16, s. 106.

${ }^{29}$ Np. ustawa z 15 kwietnia 2011 r. o działalności medycznej, Dz. U. z 2013 r., poz. 217 ze zm.

${ }^{30}$ Regulacje przedwojenne kładły szczególny nacisk na zwalczanie chorób cholery i dżumy, jak cytowana już konwencja sanitarna między Polską a Rumunią z 1923 r., czy konwencja sanitarna między Polską a Czechosłowacją z 5 września 1925 r. (Dz. U. z 1926, nr 107, poz. 629), zaś w chwili obecnej - przede wszystkim zwalczane są takie choroby jak poznane i opisane stosunkowo niedawno: AIDS, SARS, ptasia grypa (por. np. tekst Memorandum o Porozumieniu między Ministrem Zdrowia Rzeczypospolitej Polskiej a Ministerstwem Zdrowia Chińskiej Republiki Ludowej z 25 maja 2007 r. o współpracy w dziedzinie ochrony zdrowia i nauk medycznych („Monitor Polski” z 2010 r., nr 36, poz. 509). 
informacji i udostępniania ich społeczeństwu. W tym nurcie mieszczą się regulacje prawa międzynarodowego ${ }^{31}$; unijne $^{32} \mathrm{i}_{\text {krajowe }}{ }^{33}$.

3. Trzeci filar obejmuje działania służące eliminowaniu substancji szkodliwych dla zdrowia, jak np. narkotyków czy tytoniu, wprowadzanie zasad informowania o skutkach używania tych substancji, promocji zdrowego stylu życia, wolnego od nałogów, podejmowania działań wychowawczych, ochrony zdrowia osób trzecich, dotkniętych nałogiem osób najbliższych, leczenia osób uzależnionych oraz współuzależnionych, jak i reguł reklamowania tych substancji, którymi obrót jest legalny ${ }^{34}$.

4. Czwarty filar dotyczy szerokiej regulacji prawa żywnościowego, to jest bezpieczeństwa żywności i pasz, znakowania, kontroli jakości i pochodzenia produktów żywnościowych, rejestracji zakładów produkcyjnych, wymagań higienicznych, opakowań, transportu żywności śledzenia powstawania żywności „od pola do stołu” ${ }^{35}$.

31 Jak np. Konwencja sanitarna pomiędzy Polską a Rosją, Ukrainą i Białorusią z 7 lutego 1923 r., Dz. U. z 1924 r., nr 13, poz. 111, czy Konwencja sanitarna pomiędzy Polską a Rumunją z 20 grudnia 1922 r., Dz. U. z 1923 r., nr 82, poz. 636, akty prawa unijnego, przede wszystkim decyzja nr 2119/98/WE Parlamentu Europejskiego i Rady z 24 września 1998 r. ustanawiająca sieć nadzoru i kontroli epidemiologicznej chorób zakaźnych we Wspólnocie (Dz. U. UE. L. 1998.268.1 ze zm.), akty krajowe, jak np. ustawa z 5 grudnia 2008 r. o zapobieganiu oraz zwalczanie zakażeń i chorób zakaźnych u ludzi (Dz. U. nr 234, poz. 1570 ze zm.).

32 Jak przede wszystkim decyzja Parlamentu Europejskiego i Rady nr 2119/98 z 24 września 1998 r. ustanawiająca sieć nadzoru i kontroli epidemiologicznej chorób zakaźnych we Wspólnocie (Dz. U. UE.L.1998.268.1 ze zm.).

${ }_{33}$ Chodzi to przede wszystkim o ustawę z 5 grudnia 2008 r. o zapobieganiu oraz zwalczaniu zakażeń i chorób zakaźnych u ludzi (Dz. U. nr 234, poz. 1570 ze zm.).

${ }^{34}$ Najbardziej znaczącymi aktami prawa międzynarodowego są w tym zakresie: Konwencja Narodów Zjednoczonych z 20 grudnia 1988 r. o zwalczaniu nielegalnego obrotu środkami odurzającymi i substancjami psychotropowymi (Dz. U. z 1995 r., nr 15, poz. 69), Ramowa konwencja Światowej Organizacji Zdrowia o ograniczeniu użycia tytoniu z 21 maja 2003 r., Dz. U. z 2007 r., nr 74, poz. 487, wśród aktów prawa unijnego doniosłe znaczenie odgrywa dyrektywa nr 2001/37/ WE Parlamentu Europejskiego i Rady (WE) z 5 czerwca 2001 r. w sprawie zbliżenia przepisów ustawowych, wykonawczych i administracyjnych Państw Członkowskich, dotyczących produkcji, prezentowania i sprzedaży wyrobów tytoniowych (Dz. U. UE.L.2001.194.26 ze zm.) oraz rozporządzenie (WE) nr 1920/2006 Parlamentu Europejskiego i Rady z 12 grudnia 2006 r. w sprawie Europejskiego Centrum Monitorowania Narkotyków i Narkomanii (Dz. U. UE.L.2006.376.1) i Strategia antynarkotykowa UE na lata 2013-2020 (Dz. U. UE.C.2012.402.1), dyrektywa Parlamentu Europejskiego i Rady 2010/13/WE z 10 marca 2010 r. w sprawie koordynacji niektórych przepisów ustawowych, wykonawczych i administracyjnych państw członkowskich dotyczących świadczenia audiowizualnych usług medialnych (Dz. U. UE.L.2010.95.1 ze zm.), zaś podstawowymi źródłami prawa krajowego są ustawa z 9 listopada 1995 r. o ochronie zdrowia przed następstwami używania tytoniu i wyrobów tytoniowych (Dz. U. z 1996 r. nr 10, poz. 55 ze zm.).

35 Wśród aktów unijnych najistotniejsze znaczenie ma rozporządzenie WE nr 178/2002 Parlamentu Europejskiego i Rady z 28 stycznia 2002 r. ustanawiające ogólne zasady i wymagania prawa żywnościowego, powołujące Europejski Urząd ds. Bezpieczeństwa Żywności oraz ustanawiają- 
5. Piąty filar obejmuje dziedzinę prawa weterynaryjnego, zabezpieczającego zdrowie zwierząt jako surowca służącego do produkcji mięsa i wyrobów mięsnych i eliminowania zagrożeń dla ich zdrowia, a tym samym - zdrowia ludzkiego, monitorowania pochodzenia zwierząt, kontroli tzw. łańcucha żywnościowego, zasad transportu i obrotu zwierzętami, prawideł uboju, produkcji mięsa, przetwórstwa mięsnego, wytwarzania i pozbywania się odpadów wytwarzanych $\mathrm{w}$ związku z produkcją. $\mathrm{W}$ tej mierze istotne pozostają akty prawa międzynarodowego ${ }^{36}$, wiele aktów prawa unijnego ${ }^{37}$ oraz krajowego ${ }^{38}$.

6. Szósty filar określany jest poprzez ograniczenia w swobodzie działalności gospodarczej, wprowadzone w celu sprawowania należytego nadzoru nad zagrożeniami dla zdrowia ludzkiego. Chodzi tu o reglamentację niektórych gałęzi obrotu gospodarczego poprzez objęcie ich koncesjami, zezwoleniami czy niestandardową procedurą rejestracji, stałego nadzoru nad niektórymi rodzajami działalności, rejestrowania poszczególnych czynności dokonywanych przez niektórych przedsiębiorców, narzucania wymagań jakościowych w odniesieniu do produktów adresowanych do konsumentów, ustanowienia odpowiedzialności karno-administracyjnej za naruszenie zakazów lub ograniczeń. W tym obszarze istotna jest obszerna i stale powiększająca się część prawa unijnego ${ }^{39}$ oraz krajowego ${ }^{40}$.

7. Siódmy filar obejmuje obszerną dziedzinę ochrony środowiska, a zatem instrumenty służące utrzymaniu, zabezpieczeniu utrzymania właściwego dla zdrowotności publicznej (ze szczególnym uwzględnieniem przyszłych pokoleń)

ce procedury w zakresie bezpieczeństwa żywności (Dz. U. UE.L.2002.31.1 ze zm.), a podstawowym aktem krajowym jest ustawa z 26 sierpnia 2006 r. o bezpieczeństwie żywności i żywienia (Dz. U. z 2010 r., nr 136, poz. 914 ze zm.).

36 Jak np. umowa międzynarodowa między Wspólnotą Europejską a Stanami Zjednoczonymi Ameryki w sprawie sanitarnych środków ochrony zdrowia publicznego i zdrowia zwierząt w handlu żywymi zwierzętami i produktami zwierzęcymi, Dz. U. UE.L.1998.118.3 ze zm.

${ }^{37}$ Np. dyrektywa Rady z 21 listopada 1989 r. w sprawie wzajemnej pomocy między władzami administracyjnymi państw członkowskich i współpracy między państwami członkowskimi a Komisją w celu zapewnienia prawidłowego stosowania ustawodawstwa dotyczącego spraw weterynaryjnych i zootechnicznych (Dz. U. UE.L.1989.351.34 ze zm.), czy rozporządzenie Parlamentu Europejskiego i Rady (WE) nr 1069/2009 z 21 października 2009 r. określające przepisy sanitarne dotyczące produktów ubocznych pochodzenia zwierzęcego, nieprzeznaczonych do spożycia przez ludzi, i uchylające rozporządzenie (WE) nr 1774/2002 (rozporządzenie o produktach ubocznych pochodzenia zwierzęcego).

${ }^{38}$ Np. ustawa z 11 marca 2004 r. o ochronie zdrowia zwierząt oraz zwalczaniu chorób zakaźnych zwierząt (Dz. U. z 2008 r., nr 213, poz. 1342 ze zm.).

39 Jak np. dyrektywa 2001/95/WE Parlamentu Europejskiego i Rady (WE) z 3 grudnia 2001 r. w sprawie ogólnego bezpieczeństwa produktów (Dz. U. UE.L.2002.11.4 ze zm.), ustawa z 12 grudnia 2003 r. o ogólnym bezpieczeństwie produktów (Dz. U. nr 229, poz. 2275 ze zm.) i wiele innych.

${ }^{40}$ Np. ustawa z 2 lipca 2004 r. o swobodzie działalności gospodarczej (Dz. U. z 2013 r., nr 672 ze zm.), ustawa z 9 czerwca 2011 r. Prawo geologiczne i górnicze (Dz. U. nr 163, poz. 981 ze zm.). 
stanu środowiska naturalnego, ochrony gatunków zagrożonych, zasad korzystania ze środowiska przez człowieka. Dziedzina ta regulowana jest zarówno przez prawo międzynarodowe $e^{41}$, unijne ${ }^{42}$, jak i krajowe ${ }^{43}$.

8. Ósmy obszar wyznaczany jest przez zagadnienia wykonywania działalności leczniczej, regulacje zawodów lekarza i lekarza dentysty, produkcję, obrót i używanie leków oraz produktów leczniczych. Istniejące przepisy normują zasady wykonywania działalności leczniczej, funkcjonowania podmiotów wykonujących tę działalność oraz rejestrowania tej działalności, jak i nadzorowania jej przez właściwe organy administracji, wykonywania zawodu lekarza i sprawowania nadzoru w tym zakresie, nabywania i utraty uprawnień do wykonywania zawodu lekarza, form i zasad prowadzenia tej działalności, reguł wprowadzania do obrotu i wycofywania zeń leków, produktów leczniczych, odpowiedzialności z tego tytułu, podstaw do nabywania poszczególnych substancji leczniczych. Tematyka lecznictwa normowana jest przez akty unijne ${ }^{44}$ i krajowe $^{45}$.

9. Dziewiąty filar obejmuje akty dotyczące bezpieczeństwa zdrowia w zatrudnieniu, to jest regulujące bezpieczne dla zdrowia warunków pracy, w tym - zachowania higienicznego trybu życia poprzez zapewnienie odpowiednich norm czasu pracy, właściwego traktowania pracowników młodocianych, zakazu wykorzystywania pracy dzieci, egzekwowania ustanowionych w tym zakresie obowiązków pracodawców przez właściwe organy administracji publicznej. Funkcjonują tu akty prawa międzynarodowego ${ }^{46}$, unijnego ${ }^{47}$ oraz przepisy krajowe ${ }^{48}$.

$\mathrm{W}$ eksponowanych materiach ustanawiane są rozmaite narzędzia ochrony zdrowia ludzkiego jako dobra publicznego, uregulowane jednocześnie jako zadania

${ }^{41}$ Np. konwencja z 9 kwietnia 1992 r. o ochronie środowiska morskiego obszaru Morza Bałtyckiego (Dz. U. z 2000 r., nr 28, poz. 346).

42 Np. dyrektywa Rady nr 92/43/EWG z 12 maja 1992 r. w sprawie ochrony siedlisk przyrodniczych oraz dzikiej fauny i flory (Dz. U. UE.L.1992.206.7 ze zm.).

${ }_{43}$ Głównie za pomocą przepisów ustawy z 27 kwietnia 2001 r. Prawo ochrony środowiska, Dz. U. z 2008 r., $\mathrm{nr} 25$, poz. 150 ze zm.

44 Jak np. dyrektywa 2001/83/WE Parlamentu Europejskiego i Rady z 6 listopada 2001 r. w sprawie wspólnotowego kodeksu odnoszącego się do produktów leczniczych stosowanych u ludzi, Dz. U. UE.L2001.311.67 ze zm., dyrektywa nr 2005/36/WE Parlamentu Europejskiego i Rady w sprawie uznawania kwalifikacji zawodowych, Dz. U. UE.L2005.255.22 ze zm.).

45 Głównie ustawa z dnia 15 kwietnia 2011 r. o działalności leczniczej, Dz. U. z 2013 r., poz. 217, ustawa z 5 grudnia 1996 r. o zawodzie lekarza oraz lekarza dentysty (Dz. U. z 2011 r., nr 277, poz. 1634 ze zm.).

46 Przede wszystkim chodzi tu o Konstytucję Międzynarodowej Organizacji Pracy z 18 września 1946 r., Dz. U. 43, poz. 408 ze zm., Europejską Kartę Społeczną z 18 października 1961 r., Dz. U. z 1999 r., nr 8, poz. 67 ze zm., Konwencję Międzynarodowej Organizacji Pracy z 26 czerwca 1985 r., nr 161 w sprawie służb medycyny pracy, Dz. U. z 2005 r., nr 34, poz. 300.

${ }_{47}$ Np. dyrektywa Rady 12 czerwca 1989 r. w sprawie wprowadzenia środków w celu poprawy bezpieczeństwa i zdrowia pracowników w miejscu pracy, Dz. U. UE.L.1989.183.1 ze zm.

48 Zwłaszcza przepisy rozdziału X ustawy z 26 czerwca 1974 r. - Kodeks pracy (Dz. U. z 1998 r., nr 21, poz. 94 ze zm.). 
właściwych organów administracji publicznej. Ze względu na sposób oddziaływania na adresata, wyróżnić można następujące: Po pierwsze - środki o charakterze prewencyjnym, to jest zabezpieczającym zdrowie na wypadek potencjalnego zagrożenia, nie dopuszczającym do zaistnienia niebezpieczeństwa. Wskazać tu można na ponadstandardowe ${ }^{49}$ obowiązki rejestracji określonych typów działalności gospodarczej, czy zgłaszanie poszczególnych czynności przedsiębiorców ${ }^{50}$, obowiązki poddawania się szczepieniom ochronnym ${ }^{51}$. Po drugie - narzędzia kontroli i nadzoru, szczególnego rodzaju, ponad te, które wynikają z faktu podjęcia działalności gospodarczej nieobjętej szczególnym nadzorem ${ }^{52}$. Po trzecie - środki o charakterze sprawozdawczym, polegające na przedstawianiu wiadomości o wykrytych niebezpieczeństwach i podjętych działaniach oraz o ich skutkach, narzędzia niezwłocznej wymiany informacji o zaistniałych zagrożeniach ${ }^{53}$.

W ramach wymienionych tu narzędzi właściwe organy zostały wyposażone w precyzyjne zadania i kompetencje władcze realizowane $\mathrm{w}$ postaci odpowiednich prawnych form działania administracji ${ }^{54}$. Jeżeli chodzi o aktywność nadzorczo-kontrolną, rejestracyjną, sprawozdawczą, to odbywa się ona zarówno za pomocą czynności materialno-technicznych, działań społeczno-organizatorskich oraz czynności prawnych - aktów indywidualnych, tj. decyzji administracyjnych

${ }^{49} \mathrm{Tj}$. wykraczające poza powinność zgłoszenia wynikającą z art. 14 ust. 1 ustawy z 2 lipca 2004 r. o swobodzie działalności gospodarczej (Dz. U. z 2013 r., nr 672) jak np. zatwierdzanie działalności gospodarczej polegającej m.in. na produkcji nawozów organicznych i polepszaczy gleby (art. 24 ust. 1 lit. f rozporządzenia Parlamentu Europejskiego i Rady z 21 października 2009 r., nr 1069/2009, określające przepisy sanitarne dotyczące produktów ubocznych pochodzenia zwierzęcego, nieprzeznaczonych do spożycia przez ludzi, i uchylające rozporządzenie (WE) nr 1774/2002, Dz. U. UE.L.2009.300.1.

50 Jak np. zamiar wprowadzenia do obrotu nowej substancji stosowanej w produkcji żywności, zgodnie z art. 9 ust. 1 i nast. rozporządzenia (WE) nr 1935/2004 Parlamentu Europejskiego i Rady z 27 października 2004 r. w sprawie materiałów i wyrobów przeznaczonych do kontaktu z żywnością oraz uchylające dyrektywy 80/590/EWG i 89/109/EWG (Dz. U. UE.2004.338.4 ze zm.).

${ }^{51}$ Przewidziane m.in. w art. 17 ust. 1 i nast. ustawy z 5 grudnia 2008 r. o zapobieganiu oraz zwalczaniu zakażeń i chorób zakaźnych u ludzi (Dz. U. nr 234, poz. 1570 ze zm.).

52 Jak np. kontrole prowadzone wobec podmiotów produkujących żywność, przewidziane w art. 54 ust. 1 i innych rozporządzenia (WE) nr 882/2004 Parlamentu Europejskiego i Rady z 29 kwietnia 2004 r. w sprawie kontroli urzędowych przeprowadzanych w celu sprawdzenia zgodności z prawem paszowym i żywnościowym oraz regułami dotyczącymi zdrowia zwierząt i dobrostanu zwierząt (Dz. U. UE.2004.165.1 ze zm.).

${ }^{53}$ Jak np. czynności podejmowane w ramach systemu TRACES, wprowadzonego decyzją Komisji Europejskiej z 30 marca 2004 r. w sprawie wprowadzenia systemu TRACES i zmieniająca decyzję 92/486/EWG, Dz. U. UE.L.2004.94.63 ze zm., wprowadzającego jednolite w Unii Europejskiej zasady wzajemnego informowania organów państw członkowskich o wykrytych zagrożeniach dla m.in. bezpieczeństwa zdrowia i życia ludzkiego podczas kontroli transportu i tranzytu zwierząt i produktów pochodzenia zwierzęcego; system TRACES zunifikował dotychczas istniejące funkcje systemów Animo i Shift.

${ }_{54}$ Rozumiane jako określone przepisem prawa typy konkretnej czynności organu administracyjnego, por. J. Starościak, Prawne formy działania administracji, Warszawa 1957, s. 14. 
i postanowień ${ }^{55}$. W przypadku wydawania zezwoleń, nakazów albo zakazów, zwłaszcza w przypadku stwierdzenia negatywnych dla przedsiębiorcy wyników kontroli prowadzonej działalności, jak również - w przypadku stosowania sankcji administracyjnych wydawane są przede wszystkim czynności prawne - akty indywidualne, to jest decyzje administracyjne oraz postanowienia. Dodać należy, że podejmowanym przez właściwe organy decyzjom administracyjnym nadany być zawsze może rygor natychmiastowej wykonalności, bowiem niezależnie od norm prawa materialnego, ochrona życia i zdrowia ludzkiego stanowi przesłankę takiego postanowienia, przewidzianą w art. $108 \S 1$ k.p.a. ${ }^{56}$

Sumując, zdrowie człowieka stanowi dobro silne chronione normami prawa administracyjnego. Wraz z rozwojem ludzkości, nowymi technologiami produkcji, szerokimi możliwościami wykorzystywania zasobów środowiska naturalnego, pionierskimi sposobami wytwarzania żywności, pasz, leków i środków leczniczych, szybkim tempem podróży, w tym - transferem towarów, pojawiają się nowe, niespotykane dotąd zagrożenia dla zdrowia. Ustawodawca krajowy, unijny i międzynarodowy, ustanawiając liczne zadania i kompetencje istniejącym organom administracji i kreując nowe, czyni starania, by zagrożenia te były nadzorowane przez służby publiczne $\mathrm{i}$ by prawdopodobieństwo przeistoczenia się niebezpieczeństw w realne i bezpośrednie fakty uszczuplające, czy niweczące dobro chronione zostało ograniczone do minimum. Normy prawa administracyjnego cel ten realizować mogą najpełniej, są wszak instrumentem władczego oddziaływania, które wdrażane i egzekwowane może być natychmiast, niezależnie od podejmowanych przez stronę czynności odwoławczych, i to z wykorzystaniem, razie potrzeby, przymusu bezpośredniego. Dbałość o zdrowie człowieka nieodzownie prowadzi do ograniczeń swobód jednostki, zwłaszcza swobody podejmowania i prowadzenia działalności gospodarczej. Zadaniem ustawodawcy jest więc kreowanie treści prawa nie tylko surowego, ale i bilansującego obowiązki obywatela $\mathrm{z}$ prawami i wolnościami w taki sposób, by bezpieczne funkcjonowanie w nowoczesnym społeczeństwie nie stało się jednocześnie dla niego udręką w zachowaniu licznych ograniczeń, zakazów i nakazów. Wydaje się, że rolą przedstawicieli doktryny w tej nowej rzeczywistości prawnej jest zwracanie ustawodawcy uwagi na te momenty, w których omawiana równowaga ulegać może zachwianiom, a organom - na konieczność dokonywania rozsądnej wykładni licznych norm ochronnych i wyważenia interesu publicznego i interesu strony. Szczególnego znaczenia nabiera $\mathrm{w}$ omawianej dziedzinie przepis proceduralny - art. 7 k.p.a., potęgując swój potencjał normatywny w toku rozstrzygania spraw indywidualnych stycznych z powinnością zapewnienia ochrony zdrowia publicznego.

${ }^{55}$ Przyjmuję w tym miejscu klasyfikację zaproponowaną przez Z. Kmieciaka, [w:] Z. Kmieciak, J.P. Tarno, Postepowanie administracyjne oraz postepowanie przed Naczelnym Sadem Administracyjnym ( $w$ świetle orzecznictwa i doktryny), Warszawa 1988, s. 5-6.

56 Por. szerzej np. G. Łaszczyca, Postanowienie administracyjne w ogólnym postępowaniu administracyjnym, Warszawa 2012, s. 76. 